\title{
Effect of Milking Frequency on DHI Performance Measures
}

\author{
J. W. Smith, L. O. Ely, W. M. Graves, and W. D. Gilson \\ Department of Animal and Dairy Science \\ The University of Georgia, Athens 30602
}

\section{ABSTRACT}

Increasing production by increasing milking frequency $(\mathrm{MF})$ is a management option available to dairy producers. This study examined effects of MF and interactions with region and herd size on measures of herd performance. Dairy Herd Improvement (DHI) Holstein herd summary records $(\mathrm{n}=10,754,10,550$, and 10,438) for the years 1998, 1999, and 2000 were classified by MF: two times a day (2X) milking vs three times a day (3X); herd size: small ( $<250$ cows) and large $(\geq 250$ cows); and region: North and South. Percentage of herds milking $3 \mathrm{X}$ by year were 7.0, 6.7, and 7.1. Rolling herd average milk production was 16,16 , and $15 \%$ higher for herds milking $3 \mathrm{X}$ than herds milking $2 \mathrm{X}$ for the respective years. Herds milking $3 \mathrm{X}$ in the North region outproduced herds milking $3 \mathrm{X}$ in the South region. Milk fat and protein percentages were lower for herds milking $3 \mathrm{X}$ during all $3 \mathrm{yr}$. Differences in energy-corrected milk production between herds milking $3 \mathrm{X}$ and herds milking $2 \mathrm{X}$ were $14.5,13.4$, and $13.4 \%$ during the respective $3 \mathrm{yr}$ as a result of lower component percentages for herds milking $3 \mathrm{X}$. Herds milking $3 \mathrm{X}$ had more days open and higher actual calving intervals than herds milking 2X. Services per pregnancy for herds breeding primarily by artificial insemination were higher for herds milking $3 \mathrm{X}$ than for herds milking $2 \mathrm{X}$. Somatic cell scores and weighted somatic cell counts were lower for herds milking 3X than herds milking 2X. Herds milking $3 \mathrm{X}$ had a higher percentage of somatic cell scores in the low range ( 0 to 3 ) and a lower percentage in the high range (7 to 9 ). Mean percentages of cows entering and leaving the herd were higher for herds milking $3 \mathrm{X}$ during all $3 \mathrm{yr}$.

(Key words: Dairy Herd Improvement, frequency, management, milking)

Abbreviation key: CMT = California mastitis test, $\mathbf{E C M}=$ energy-corrected milk, $\mathbf{M F}=$ milking frequency, $\mathbf{3 X}=$ three times a day, $\mathbf{2} \mathbf{X}=$ two times a day.

Received April 19, 2002.

Accepted June 20, 2002.

Corresponding author: J. W. Smith; e-mail: jimsmith@uga.edu.

\section{INTRODUCTION}

Many dairy producers seek higher levels of production in response to increased costs of production and a tendency for static or lower milk prices. Increasing production by increasing milking frequency (MF) to three times a day $(\mathbf{3 X})$ is one management option. Increased efficiency through parlor automation and mechanization have made $3 \mathrm{X}$ milking an attractive option for some herds.

Most studies conducted on MF have measured the effect of milking $3 \mathrm{X}$ on milk yield and components. Total milk yield is higher from cows milked $3 \mathrm{X}$ (Amos et al., 1985; DePeters et al., 1985; Allen et al., 1986; Gisi et al., 1986; Barnes et al., 1990). Higher production from $3 \mathrm{X}$ milking is usually expressed as a percentage (Gisi et al., 1986; Campos et al., 1994). However, an analysis of previously published reports found that increasing MF from two times a day $(\mathbf{2 X})$ to $3 \mathrm{X}$ resulted in a fixed increase of $3.5 \mathrm{~kg} / \mathrm{d}$ in milk yield and $92 \mathrm{~g} /$ day in fat yield independent of parity (Erdman and Varner, 1995).

Some studies (Allen et al., 1986; Barnes et al., 1990; Speicher et al., 1994) reported a lower concentration of milk components from cows milked 3X, whereas others (Amos et al., 1985; DePeters et al., 1985) did not report any significant changes. The percentage of $\mathrm{CP}$ was lower for cows milked $3 \mathrm{X}$ than cows milked $2 \mathrm{X}$ during each lactation stage (Klei et al., 1997). A lower concentration of fat and casein from cows milked $3 \mathrm{X}$ could result in lower cheese yield. (Sapru et al., 1997).

Reproduction performance was not altered by $3 \mathrm{X}$ milking in some studies, whereas others have shown a trend for reduced reproductive performance. Barnes et al. (1990) concluded that MF did not alter days to first service, inseminations per conception, or days open. Reproductive performance was not influenced by MF, but there was a trend for increased days open in a study by Amos et al. (1985). They concluded that further research with larger numbers of cows may be required to define more clearly the influence of $3 \mathrm{X}$ milking on total reproductive performance. DePeters et al. (1985) reported a trend for poorer reproductive performance of cows milked 3X than cows milked 2X. Gisi et al. (1986) found no effect of 3X milking on calving interval, days open, or services per conception, but reproductive 
indexes on a herd basis tended to increase as milking $3 \mathrm{X}$ increased. In a California study, $3 \mathrm{X}$ milking was associated with more days open in first-lactation cows and a greater number of breedings per conception in both first- and second-lactation cows (Allen et al., 1986).

Most studies have reported little or no effect of 3X milking on udder health (DePeters et al., 1985; Gisi et al., 1986). A trend for lower SCC in cows milked 3X (Klei et al., 1997), and a reduction in Wisconsin mastitis test scores and a slightly lower incidence of mastitis in 3X milked cows was reported (Pearson et al., 1979). Cows milked $3 \mathrm{X}$ up to the third lactation had higher California mastitis test (CMT) scores than cows milked 2X. Fourth and later lactation cows milked $3 \mathrm{X}$ had lower CMT scores than cows milked 2X (Allen et al., 1986). Bulk tank SCC declined from 193,000 to 162,000 cells/ml when cows were changed to $3 \mathrm{X}$ milking (Hogeveen et al., 2001). The number of cows with SCC greater than 250,000 cells $/ \mathrm{ml}$ also decreased. When herds resumed $2 \mathrm{X}$ milking the trends reversed.

Reports of the effect of 3X milking on other herd management factors are limited. Allen et al. (1986) reported that fewer cows were culled from herds milking $3 X$ across all parities. Gisi et al. (1986) reported that the response to $3 \mathrm{X}$ milking in 28 California herds was not related to herd size or production level when on 2X milking.

The decision to begin or continue $3 \mathrm{X}$ milking should be based on profitability. Culotta and Schmidt (1988) concluded from an economic evaluation that with their current milk and feed prices, 3X milking would be profitable only if the increased cost of labor were very low, large percentages in milk yield due to $3 \mathrm{X}$ milking were obtained, or if high milk yield per cow already existed on $2 \mathrm{X}$ milking.

The objective of this study was to determine the effect of $\mathrm{MF}$ and the interaction of MF with herd size and region on DHI measures of performance.

\section{MATERIALS AND METHODS}

Herd summary records from DHI for the years 1998, 1999, and 2000 were obtained from Dairy Records Management Systems (Raleigh, North Carolina). Holstein herds with 30 or more cows, a minimum rolling herd average of $6350 \mathrm{~kg}$, and a last test date between November 1 and December 31 were included. Herd size groups were small $(<250$ cows $)$ and large $(\geq 250$ cows). Herds within a state were assigned to North and South regions as shown in Figure 1. Energy-corrected milk (ECM) production was calculated as $\mathrm{ECM}=(0.3246 \times \mathrm{kg}$ of milk $)+(12.86 \times \mathrm{kg}$ of fat $)+(7.04 \times \mathrm{kg}$ of protein $)$. Herds were classified for analysis of reproductive variables. The All class included all herds regardless of percentage

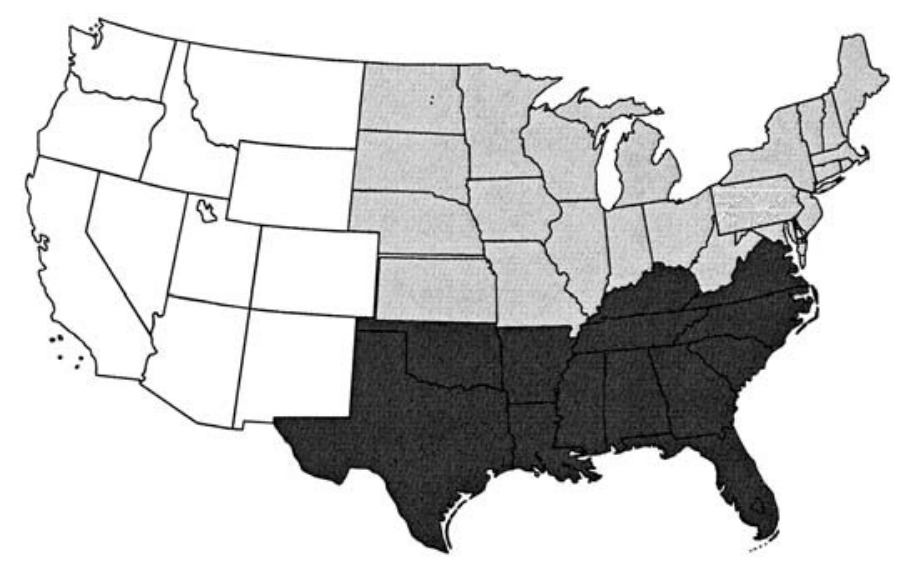

Figure 1. Assignment of states to north and south regions.

of AI service sire usage. The AI class was limited to herds using $70 \%$ or more AI service sires and an average services per pregnancy $\geq 1.5$. Bovine somatotropin usage is not routinely reported on DHI records. An equal distribution of bST usage across all herd groups regardless of region and MF was assumed in this study.

Data were analyzed using SAS PROC GLM for main effects ( $M F$, size, region) and two-way interactions ( $M F$ $\times$ size, $M F \times$ region) $($ SAS, 1996). Least squares means were compared by the Tukey option of SAS PROC GLM (SAS, 1997). The level of significance used was $P<0.05$. Only significant main effects for MF and MF interactions are reported and discussed.

\section{RESULTS AND DISCUSSION}

The distribution of herds by MF, MF by herd size, and MF by region is shown in Table 1 . The percentage of herds milking $3 \mathrm{X}$ was similar across years. The percentage of large herds milking both $2 \mathrm{X}$ and $3 \mathrm{X}$ increased by year, whereas the percentage of small herds milking $3 \mathrm{X}$ declined. The trend of $3 \mathrm{X}$ milking was similar across regions.

\section{Milk Production and Composition}

Milk production was significantly higher for herds milking $3 \mathrm{X}$ for all years $(P<0.05$; Table 2$)$. Herds milking $3 \mathrm{X}$ produced 16,16 , and $15 \%$ more milk than herds milking $2 \mathrm{X}$ during the respective years. Small and large herds milking $3 \mathrm{X}$ did not differ in production except in the year 2000. Herds in the North significantly outproduced herds in the South in 1998 and 1999 irrespective of MF $(P<0.05)$. The higher milk yield by cows and herds milked $3 \mathrm{X}$ agrees with other studies (Amos et al., 1985; DePeters et al., 1985; Allen et al., 1986; Gisi et al., 1986; and Barnes et al., 1990). Reviews of previous 
Table 1. Percentage and number of herds for milking frequency (MF), MF by herd size, and MF within region for 1998,1999 , and 2000.

\begin{tabular}{|c|c|c|c|c|c|c|c|}
\hline \multirow[b]{2}{*}{ MF } & & \multicolumn{2}{|c|}{1998} & \multicolumn{2}{|c|}{1999} & \multicolumn{2}{|c|}{2000} \\
\hline & & Percent & No. & Percent & No. & Percent & No. \\
\hline $2 \mathrm{X}$ & & 93.0 & 9999 & 93.1 & 9819 & 92.9 & 9701 \\
\hline $3 \mathrm{X}$ & Herd Size ${ }^{1}$ & 7.0 & 755 & 6.9 & 731 & 7.1 & 737 \\
\hline $2 \mathrm{X}$ & Large & 3.9 & 417 & 4.2 & 449 & 4.7 & 487 \\
\hline $2 \mathrm{X}$ & Small & 89.1 & 9582 & 88.8 & 9370 & 88.3 & 9214 \\
\hline $3 \mathrm{X}$ & Large & 3.2 & 339 & 3.4 & 360 & 3.8 & 397 \\
\hline $3 \mathrm{X}$ & $\begin{array}{l}\text { Small } \\
\text { Region }^{2}\end{array}$ & 3.8 & 416 & 3.5 & 371 & 3.2 & 340 \\
\hline $2 \mathrm{X}$ & North & 76.9 & 8274 & 77.4 & 8165 & 76.9 & 8024 \\
\hline $2 \mathrm{X}$ & South & 16.0 & 1725 & 15.7 & 551 & 16.1 & 570 \\
\hline $3 \mathrm{X}$ & North & 5.4 & 579 & 5.2 & 1654 & 5.4 & 1677 \\
\hline $3 \mathrm{X}$ & South & 1.6 & 176 & 1.7 & 180 & 1.6 & 167 \\
\hline
\end{tabular}

${ }^{1}$ Herd sizes are large ( $\geq 250$ cows) and small ( $<250$ cows).

${ }^{2}$ Regions are North and South (see Figure 1).

reports by other researchers (Campos et al., 1994; Klei et al., 1997) suggest an average expected increase of about 12 to $15 \%$ when herds change from $2 \mathrm{X}$ to $3 \mathrm{X}$ milking. Milk yield increased $12 \%$ above previous $2 \mathrm{X}$ production on 28 California Holstein herds based on DHI herd summary records (Gisi et al., 1986). Herds in our study are designated $3 \mathrm{X}$ if the cows were milked $3 \mathrm{X}$ for all or any part of the yearly period. True 3X milk yield is probably higher than that shown in Table 2 because an unknown number of herds were milked $2 \mathrm{X}$ for part of the year, but production records for those herds were included in the summarized $3 \mathrm{X}$ yield. Because $3 \mathrm{X}$ herds in the current report averaged 15 to $16 \%$ more milk compared with studies reporting slightly lower percentage differences, undefined management factors other than MF may account for some of the observed milk yield differences.

Milk fat and protein percentages were significantly lower for herds milking $3 \mathrm{X}$ during all $3 \mathrm{yr}(P<0.05$; Table 3). Although milk from herds milking $2 \mathrm{X}$ in the North had a higher percentage of milk fat than herds milking $2 \mathrm{X}$ in the South, herds milking $3 \mathrm{X}$ did not differ by region. Herds milking $2 \mathrm{X}$ and $3 \mathrm{X}$ in the South had a significantly higher protein percentage in two out of the three years $(P<0.05)$. Milk composition was not affected by MF in studies by Amos et al. (1985) and DePeters et al. (1985). Milk fat percentage was not affected by MF (Gisi et al. (1986). Allen et al. (1986)

Table 2. Effect of milking frequency (MF) and interactions of MF with herd size and MF with region on herd average milk production ${ }^{1}$ for 1998,1999 , and 2000.

\begin{tabular}{|c|c|c|c|c|}
\hline & 1998 & 1999 & 2000 \\
\hline \multirow{4}{*}{$\begin{array}{l}2 \mathrm{X} \\
3 \mathrm{X} \\
\text { Difference, \% } \\
\text { SEM }\end{array}$} & & $8698^{b}$ & $8853^{b}$ & $9013^{\mathrm{b}}$ \\
\hline & & $10,086^{\mathrm{a}}$ & $10,163^{\mathrm{a}}$ & $10,386^{\mathrm{a}}$ \\
\hline & & 16 & 16 & 15 \\
\hline & & 44 & 43 & 44 \\
\hline $2 \mathrm{X}$ & $\begin{array}{l}\text { Herd Size } \\
\text { Large }\end{array}$ & $8732^{\mathrm{b}}$ & $8942^{\mathrm{b}}$ & $9081^{\mathrm{c}}$ \\
\hline $2 \mathrm{X}$ & Small & $8663^{b}$ & $8764^{\mathrm{b}}$ & $8946^{\mathrm{c}}$ \\
\hline $3 \mathrm{X}$ & Large & $9994^{\mathrm{a}}$ & $10,057^{\mathrm{a}}$ & $10,170^{b}$ \\
\hline $3 \mathrm{X}$ & Small & $10,179^{\mathrm{a}}$ & $10,268^{\mathrm{a}}$ & $10,603^{\mathrm{a}}$ \\
\hline \multirow[t]{2}{*}{ SEM } & & 57 & 57 & 58 \\
\hline & $\begin{array}{l}\text { Region }{ }^{3} \\
\text { North }\end{array}$ & $9089^{c}$ & $9289^{b}$ & 9423 \\
\hline $2 \mathrm{X}$ & South & $8307^{\mathrm{d}}$ & $8416^{\mathrm{c}}$ & $\begin{array}{l}9420 \\
8604\end{array}$ \\
\hline $3 \mathrm{X}$ & North & $10,654^{\mathrm{a}}$ & $10,806^{\mathrm{a}}$ & 10,891 \\
\hline $3 \mathrm{X}$ & South & $9518^{b}$ & $9519^{b}$ & 9882 \\
\hline SEM & & 59 & 59 & 60 \\
\hline
\end{tabular}


Table 3. Effect of milking frequency $(\mathrm{MF})$ and interaction of $\mathrm{MF}$ with region on milk fat and protein percentages $^{1}$ for 1998,1999 , and 2000.

\begin{tabular}{|c|c|c|c|c|c|c|c|}
\hline \multirow[b]{2}{*}{ MF } & & \multicolumn{3}{|c|}{ Fat } & \multicolumn{3}{|c|}{ Protein } \\
\hline & & 1998 & 1999 & 2000 & 1998 & 1999 & 2000 \\
\hline $2 \mathrm{X}$ & & $3.64^{\mathrm{a}}$ & $3.64^{\mathrm{a}}$ & $3.67^{\mathrm{a}}$ & $3.19^{\mathrm{a}}$ & $3.22^{\mathrm{a}}$ & $3.10^{\mathrm{a}}$ \\
\hline $3 \mathrm{X}$ & & $3.54^{b}$ & $3.57^{\mathrm{b}}$ & $3.58^{b}$ & $3.15^{\mathrm{b}}$ & $3.19^{b}$ & $3.08^{b}$ \\
\hline SEM & & 0.01 & 0.01 & 0.01 & 0.004 & 0.004 & 0.003 \\
\hline $2 \mathrm{X}$ & $\begin{array}{l}\text { Region } \\
\text { North }\end{array}$ & $3.72^{\mathrm{a}}$ & $3.70^{\mathrm{a}}$ & $3.74^{\mathrm{a}}$ & 3.19 & $3.20^{\mathrm{b}}$ & $3.09^{b}$ \\
\hline $2 \mathrm{X}$ & South & $3.56^{\mathrm{b}}$ & $3.57^{\mathrm{b}}$ & $3.61^{b}$ & 3.19 & $3.24^{\mathrm{a}}$ & $3.12^{\mathrm{a}}$ \\
\hline $3 \mathrm{X}$ & North & $3.58^{b}$ & $3.59^{b}$ & $3.61^{b}$ & 3.14 & $3.15^{\mathrm{c}}$ & $3.05^{\mathrm{c}}$ \\
\hline $3 \mathrm{X}$ & South & $3.50^{\mathrm{b}}$ & $3.56^{\mathrm{b}}$ & $3.55^{\mathrm{b}}$ & 3.16 & $3.24^{\mathrm{a}}$ & $3.12^{\mathrm{a}}$ \\
\hline SEM & & 0.01 & 0.01 & 0.01 & 0.005 & 0.005 & 0.005 \\
\hline
\end{tabular}

reported a slightly lower milk fat percentage from cows milked $3 \mathrm{X}$ compared with cows milked $2 \mathrm{X}$. Increasing $\mathrm{MF}$ from $2 \mathrm{X}$ to $3 \mathrm{X}$ reduced milk fat percentage from multiparous cows and reduced protein percentage from multiparous and primiparous cows (Speicher et al., 1994). In a study by Barnes et al. (1990), cows milked $3 \mathrm{X}$ had a lower fat percentage and tended to weigh less than cows milked $2 \mathrm{X}$. This suggested that more body tissue was catabolized for milk production because DMI was not different between the MF groups. Klei et al. (1997) reported a lower percentage of CP in milk from cows milked 2X during all lactation stages. Milk from cows milked $3 \mathrm{X}$ had a lower concentration of milkfat and casein than milk from cows milked $2 \mathrm{X}$ in a study by Sapru et al. (1997).

ECM production for herds milking both $2 \mathrm{X}$ and $3 \mathrm{X}$ followed a trend similar to actual milk production (Table 4). However, the difference between the ECM production of herds milking $2 \mathrm{X}$ and herds milking $3 \mathrm{X}$ was less than the difference between $2 \mathrm{X}$ and $3 \mathrm{X}$ actual milk production during all $3 \mathrm{yr}$. The smaller difference for ECM production is the result of the significantly lower fat and protein percentages for herds milked 3X. The effect of MF on ECM has not been reported previously.

\section{Reproduction}

Projected days open were significantly higher $(P<$ 0.05 ) for both All herds and AI herds milked 3X across all $3 \mathrm{yr}$ (Table 5 ). Herds milked $3 \mathrm{X}$ in the South tended to have the most days open, but this was significant only in the year $2000(P<0.05)$. The effect of MF on actual calving interval followed the same trend as projected days open (Table 6). The actual calving interval was significantly higher for herds milked $3 \mathrm{X}$ each year $(P<0.05)$. Milking frequency did not significantly affect days to first service for AI herds. The number of services per pregnancy was significantly affected by MF $(P<$ 0.05 ; Table 7). The number of services per pregnancy for all cows and for pregnant cows was significantly higher for herds milked $3 \mathrm{X}$ during all $3 \mathrm{yr}(P<0.05)$. Large-size herds milked $3 \mathrm{X}$ tended to have the most services per pregnancy, but the interaction was significant only in the year 2000 for the pregnant cows category $(P<0.05)$.

Other studies generally have not reported a significant effect of $3 \mathrm{X}$ milking on reproductive efficiency. Increased MF did not significantly affect conception rates or days open in a study by Barnes et al. (1990). Amos et al. (1985) reported that reproductive performance was not significantly altered by MF as measured by days to first estrus, days open, and services per conception. However, days open for cows milked 3X were longer by a numerical average of $18.1 \mathrm{~d}$. Gisi et al. (1986) also did not find a significant difference in reproductive indexes with $3 \mathrm{X}$ milking, but there was a trend for the indexes to increase with $3 \mathrm{X}$ milking. The influence of $3 \mathrm{X}$ milking on reproductive performance may be related to parity. Allen et al. (1986) concluded that milking cows $3 \mathrm{X}$ had no adverse effect on reproductive efficiency. However, first-lactation cows milked $3 \mathrm{X}$ had more days open compared with cows milked 2X. Milking frequency did not affect days open for second-lactation cows. Third, fourth, and later parity cows milked 3X had fewer days open than cows milked $2 \mathrm{X}$. The number of breedings for first- and second-lactation cows milked $3 \mathrm{X}$ was significantly higher than for cows milked $2 \mathrm{X}$. There was no difference for cows in their third or later lactations.

Reproductive performance of cows milked $3 \mathrm{X}$ was not significantly different from cows milked $2 \mathrm{X}$ as reported by DePeters (1985). However, all indices of reproductive 
Table 4. Effect of milking frequency (MF) and interactions of MF with herd size and MF with region on herd energy-corrected milk (ECM) production ${ }^{1}$ for 1998 , 1999, and 2000.

\begin{tabular}{|c|c|c|c|c|}
\hline $\mathrm{MF}$ & & 1998 & 1999 & 2000 \\
\hline $2 \mathrm{X}$ & & $8959^{b}$ & $9131^{b}$ & $9270^{b}$ \\
\hline $3 \mathrm{X}$ & & $10,264^{\mathrm{a}}$ & $10,360^{\mathrm{a}}$ & $10,517^{\mathrm{a}}$ \\
\hline Difference, $\%$ & & 14.5 & 13.4 & 13.4 \\
\hline SEM & & 52 & 50 & 51 \\
\hline & Herd Size ${ }^{2}$ & $9095^{\mathrm{b}}$ & $9454^{c}$ & $9438^{b}$ \\
\hline $\begin{array}{l}2 \mathrm{Z} \\
2 \mathrm{X}\end{array}$ & $\begin{array}{l}\text { Large } \\
\text { Small }\end{array}$ & $\begin{array}{l}9095^{\circ} \\
8822^{c}\end{array}$ & $\begin{array}{l}9454^{\mathrm{b}} \\
8972^{\mathrm{b}}\end{array}$ & $\begin{array}{l}9438^{\circ} \\
9102^{c}\end{array}$ \\
\hline $3 \mathrm{X}$ & Large & $10,220^{\mathrm{a}}$ & $10,314^{\mathrm{a}}$ & $10,358^{\mathrm{a}}$ \\
\hline $3 \mathrm{X}$ & Small & $10,308^{\mathrm{a}}$ & $10,406^{\mathrm{a}}$ & $10,677^{\mathrm{a}}$ \\
\hline SEM & Region $^{3}$ & 66 & 64 & 64 \\
\hline $2 \mathrm{X}$ & North & 9369 & $9539^{b}$ & 9640 \\
\hline $2 \mathrm{X}$ & South & 8549 & $8724^{c}$ & 8900 \\
\hline $3 \mathrm{X}$ & North & 10,740 & $10,924^{\mathrm{a}}$ & 10,940 \\
\hline $3 \mathrm{X}$ & South & 9789 & $9796^{\mathrm{b}}$ & 10,094 \\
\hline SEM & & 69 & 68 & 149 \\
\hline
\end{tabular}

${ }^{a b c}$ Least squares means within column for main effect or interactions with the same superscripts do not differ $(\mathrm{P}<0.05)$.

${ }^{1}$ Calculated using DHI rolling herd average milk, fat, and protein production $(\mathrm{ECM}=[0.346 \times \mathrm{kg}$ of milk $]$ $+[12.86 \times \mathrm{kg}$ of fat $]+[7.04 \times \mathrm{kg}$ of protein $]$.

${ }^{2}$ Herd sizes are large $(\geq 250$ cows) and small ( $<250$ cows).

${ }^{3}$ Regions are North and South (see Figure 1).

Table 5. Effect of milking frequency (MF) and the interaction of MF and region on projected days open for All herds and AI herds. ${ }^{1}$

\begin{tabular}{|c|c|c|c|c|c|c|c|}
\hline \multirow[b]{2}{*}{ MF } & & \multicolumn{3}{|c|}{ All herds } & \multicolumn{3}{|c|}{ AI herds } \\
\hline & & 1998 & 1999 & 2000 & 1998 & 1999 & 2000 \\
\hline $2 \mathrm{X}$ & & $163.0^{\mathrm{b}}$ & $164.4^{\mathrm{b}}$ & $162.4^{\mathrm{b}}$ & $157.7^{\mathrm{b}}$ & $158.8^{\mathrm{b}}$ & $157.3^{\mathrm{b}}$ \\
\hline $3 \mathrm{X}$ & & $169.4^{\mathrm{a}}$ & $171.2^{\mathrm{a}}$ & $168.6^{\mathrm{a}}$ & $164.8^{\mathrm{a}}$ & $164.4^{\mathrm{a}}$ & $165.9^{\mathrm{a}}$ \\
\hline SEM & & 1.2 & 1.2 & 1.2 & 1.3 & 1.3 & 1.3 \\
\hline $2 \mathrm{X}$ & $\begin{array}{l}\text { Region }^{3} \\
\text { North }\end{array}$ & $155.7^{\mathrm{a}}$ & $156.9^{\mathrm{a}}$ & $154.4^{\mathrm{c}}$ & $1495^{\mathrm{a}}$ & $1508^{\mathrm{a}}$ & $149.8^{\mathrm{c}}$ \\
\hline $2 \mathrm{X}$ & South & $170.2^{\mathrm{a}}$ & $171.9^{\mathrm{a}}$ & $170.4^{\mathrm{b}}$ & $166.0^{\mathrm{a}}$ & $166.9^{\mathrm{a}}$ & $164.9^{\mathrm{b}}$ \\
\hline $3 \mathrm{X}$ & North & $159.4^{\mathrm{a}}$ & $161.5^{\mathrm{a}}$ & $156.2^{\mathrm{c}}$ & $155.4^{\mathrm{a}}$ & $156.7^{\mathrm{a}}$ & $152.8^{\mathrm{c}}$ \\
\hline $3 \mathrm{X}$ & South & $179.4^{\mathrm{a}}$ & $180.8^{\mathrm{a}}$ & $180.9^{\mathrm{a}}$ & $174.1^{\mathrm{a}}$ & $172.1^{\mathrm{a}}$ & $179.0^{\mathrm{a}}$ \\
\hline SEM & & 1.7 & 1.7 & 1.7 & 1.7 & 1.8 & 1.7 \\
\hline
\end{tabular}

${ }^{a b c}$ Least squares means within column for main effect or interactions with the same superscripts do not differ $(\mathrm{P}<0.05)$.

${ }^{1}$ All herds includes herds regardless of AI service sire usage. AI herds are limited to herds using $70 \%$ or more AI service sires and services per pregnancy $\geq 1.5$.

${ }^{3}$ Regions are North and South (see Figure 1).

Table 6. Effect of milking frequency (MF) on actual calving interval for All herds and AI herds. ${ }^{1}$

\begin{tabular}{|c|c|c|c|c|c|c|}
\hline \multirow[b]{2}{*}{$\mathrm{MF}$} & \multicolumn{3}{|c|}{ All herds } & \multicolumn{3}{|c|}{ AI herds } \\
\hline & 1998 & 1999 & 2000 & 1998 & 1999 & 2000 \\
\hline $2 \mathrm{X}$ & $13.77^{\mathrm{b}}$ & $13.97^{\mathrm{b}}$ & $14.02^{\mathrm{b}}$ & $13.86^{\mathrm{b}}$ & $14.07^{\mathrm{b}}$ & $14.11^{\mathrm{b}}$ \\
\hline $3 \mathrm{X}$ & $13.95^{\mathrm{a}}$ & $14.20^{\mathrm{a}}$ & $14.25^{\mathrm{a}}$ & $13.98^{\mathrm{a}}$ & $14.27^{\mathrm{a}}$ & $14.29^{\mathrm{a}}$ \\
\hline SEM & 0.03 & 0.03 & 0.03 & 0.04 & 0.04 & 0.04 \\
\hline
\end{tabular}

${ }^{\mathrm{ab}}$ Least squares means within a column with the same superscript do not differ $(\mathrm{P}<0.05)$.

${ }^{1}$ All herds includes herds regardless of AI service sire usage. AI herds are limited to herds using $70 \%$ or more AI service sires and services per pregnancy $\geq 1.5$. 
Table 7. Effect of milking frequency (MF) and the interaction of MF and herd size on services per pregnancy.

\begin{tabular}{|c|c|c|c|c|c|c|c|}
\hline \multirow[b]{2}{*}{$\mathrm{MF}$} & & \multicolumn{3}{|c|}{ Services per pregnancy (pregnant) ${ }^{1}$} & \multicolumn{3}{|c|}{ Services per pregnancy $(\text { all })^{2}$} \\
\hline & & 1998 & 1999 & 2000 & 1998 & 1999 & 2000 \\
\hline $2 \mathrm{X}$ & & $3.79^{b}$ & $3.76^{\mathrm{b}}$ & $3.69^{b}$ & $2.36^{\mathrm{b}}$ & $2.42^{\mathrm{b}}$ & $2.40^{\mathrm{b}}$ \\
\hline $3 \mathrm{X}$ & & $4.17^{\mathrm{a}}$ & $4.09^{\mathrm{a}}$ & $4.17^{\mathrm{a}}$ & $2.45^{\mathrm{a}}$ & $2.52^{\mathrm{a}}$ & $2.53^{\mathrm{a}}$ \\
\hline SEM & Herd Size ${ }^{3}$ & 0.05 & 0.04 & 0.04 & 0.02 & 0.02 & 0.02 \\
\hline $2 \mathrm{X}$ & Large & $4.12^{\mathrm{a}}$ & $4.08^{\mathrm{a}}$ & $3.97^{\mathrm{b}}$ & $2.47^{\mathrm{a}}$ & $2.52^{\mathrm{a}}$ & $2.50^{\mathrm{a}}$ \\
\hline $2 \mathrm{X}$ & Small & $3.46^{\mathrm{a}}$ & $3.44^{\mathrm{a}}$ & $3.42^{\mathrm{c}}$ & $2.26^{\mathrm{a}}$ & $2.32^{\mathrm{a}}$ & $2.30^{\mathrm{b}}$ \\
\hline $3 \mathrm{X}$ & Large & $4.39^{\mathrm{a}}$ & $4.33^{\mathrm{a}}$ & $4.29^{\mathrm{a}}$ & $2.53^{\mathrm{a}}$ & $2.59^{\mathrm{a}}$ & $2.58^{\mathrm{a}}$ \\
\hline $3 \mathrm{X}$ & Small & $3.96^{\mathrm{a}}$ & $3.85^{\mathrm{a}}$ & $4.05^{\mathrm{b}}$ & $2.37^{\mathrm{a}}$ & $2.44^{\mathrm{a}}$ & $2.48^{\mathrm{a}}$ \\
\hline SEM & & 0.06 & 0.05 & 0.05 & 0.02 & 0.02 & 0.02 \\
\hline
\end{tabular}

${ }^{a b}$ Least squares means within a column with the same superscript do not $\operatorname{differ}(\mathrm{P}<0.05)$.

${ }^{1}$ Services per pregnancy for pregnant cows.

${ }^{2}$ Services per pregnancy for all cows.

${ }^{3}$ Herd sizes were large ( $\geq 250$ cows) or small ( $<250$ cows).

performance were poorer for cows milked $3 \mathrm{X}$ compared with cows milked $2 \mathrm{X}$ with the greatest effect on first lactation cows. The authors concluded that the poor reproductive performance of cows milked $3 \mathrm{X}$ may be related to large changes in $\mathrm{BW}$ over the lactation in response to milk yield.

Butler and Smith (1989) evaluated the loss in BCS during the first $5 \mathrm{wk}$ postpartum as well as reproductive performance. Days to first ovulation, days to first estrus, and days to first service increased whereas firstservice conception rate decreased with greater loss in BCS. Spaulding et al. (1975) reported that the level of milk production had an inverse relationship with fertility and reproduction for given ages and herd sizes.

\section{Udder Health}

SCC score and weighted SCC were significantly lower $(P<0.05)$ for herds milked $3 \mathrm{X}$ compared to herds milked $2 \mathrm{X}$ during all $3 \mathrm{yr}$ (Table 8). Herds milked $3 \mathrm{X}$ had a significantly higher percentage of SCS in the low (0 to 3 ) range, and a lower percentage in the high range (7 to 9 ) during the 3 -yr period ( $P<0.05$; Table 9 ). Information on the effect of $3 \mathrm{X}$ milking on udder health is limited. Udder health was not affected by $3 \mathrm{X}$ milking based on California mastitis scores (Gisi et al., 1986) and the incidence of clinical mastitis cases (DePeters et al., 1985). Allen et al. (1986) found that udder health as measured by California mastitis test (CMT) scores was lower for cows milked 3X. Cows milked 3X up to the third lactation had higher CMT scores than cows milked 2X. Fourth and later lactation cows had lower CMT scores. Klei et al. (1997) reported slightly lower SCC for cows milked 3X. Hogeveen et al. (2001) used data from 57 herds and observed that changing from $2 \mathrm{X}$ to $3 \mathrm{X}$ milking resulted in a bulk tank SCC decrease from 193,000 to 162,000 cells $/ \mathrm{ml}$. The authors also reported a decrease in the number of cows with cell counts greater than 250,000 cells $/ \mathrm{ml}$. When herds resumed milking $2 \mathrm{X}$ the trend reversed.

\section{Entering and Leaving the Herd}

The percentage of cows entering the herd and the percentage leaving the herd were significantly higher for herds milked $3 \mathrm{X}$ during all $3 \mathrm{yr}(P<0.05$; Table 10$)$. The percentage of cows leaving the herd and milked $3 \mathrm{X}$ in the South was significantly higher than the North only in $1998(P<0.05)$. The higher culling rate for herds milked $3 \mathrm{X}$ in our study is in contrast to other studies. Allen et al. (1986) reported fewer cows culled from herds milked $3 \mathrm{X}$ and concluded that there appeared to be no

Table 8. Effect of milking frequency (MF) on SCS and weighted somatic cell counts (WSCC).

\begin{tabular}{|c|c|c|c|c|c|c|}
\hline \multirow[b]{2}{*}{$\mathrm{MF}$} & \multicolumn{3}{|c|}{ SCS } & \multicolumn{3}{|c|}{ WSCC } \\
\hline & 1998 & 1999 & 2000 & 1998 & 1999 & 2000 \\
\hline & & & & & 1000 & 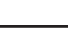 \\
\hline $2 \mathrm{X}$ & $3.23^{\mathrm{a}}$ & $3.22^{\mathrm{a}}$ & $3.21^{\mathrm{a}}$ & $368^{\mathrm{a}}$ & $356^{\mathrm{a}}$ & $352^{\mathrm{a}}$ \\
\hline $3 \mathrm{X}$ & $3.03^{\mathrm{b}}$ & $3.05^{\mathrm{b}}$ & $3.08^{\mathrm{b}}$ & $331^{\mathrm{b}}$ & $332^{\mathrm{b}}$ & $341^{\mathrm{b}}$ \\
\hline SEM & 0.03 & 0.02 & 0.02 & 5 & 5 & 5 \\
\hline
\end{tabular}

${ }^{\mathrm{ab}}$ Least squares means within a column with the same superscript do not differ $(\mathrm{P}<0.05)$. 
Table 9. Effect of milking frequency (MF) on the percent of high (0 to 3) and low (7 to 9) SCS by year.

\begin{tabular}{lccccccc}
\hline & \multicolumn{3}{c}{ SCC 0 to 3} & & \multicolumn{3}{c}{ SCC 7 to 9} \\
\cline { 2 - 4 } MF & 1998 & 1999 & 2000 & & 1998 & 1999 & 2000 \\
\hline $2 \mathrm{X}$ & $58.0^{\mathrm{b}}$ & $58.4^{\mathrm{b}}$ & $58.4^{\mathrm{b}}$ & $8.8^{\mathrm{a}}$ & $8.4^{\mathrm{a}}$ & $8.3^{\mathrm{a}}$ \\
$3 \mathrm{X}$ & $62.1^{\mathrm{a}}$ & $61.4^{\mathrm{a}}$ & $61.2^{\mathrm{a}}$ & & $7.9^{\mathrm{b}}$ & $7.9^{\mathrm{b}}$ & $8.3^{\mathrm{a}}$ \\
SEM & 0.43 & 0.42 & 0.42 & & 0.15 & 0.15 & 0.15 \\
\hline
\end{tabular}

${ }^{\mathrm{ab}}$ Least squares means within a column with the same superscript do not $\operatorname{differ}(\mathrm{P}<0.05)$.

Table 10. Effect of milking frequency (MF) and interaction of MF with region on the percentage of cows entering and leaving the herd.

\begin{tabular}{|c|c|c|c|c|c|c|c|}
\hline \multirow[b]{2}{*}{$\mathrm{MF}$} & & \multicolumn{3}{|c|}{ Entering } & \multicolumn{3}{|c|}{ Leaving } \\
\hline & & 1998 & 1999 & 2000 & 1998 & 1999 & 2000 \\
\hline $2 \mathrm{X}$ & & $38.4^{\mathrm{b}}$ & $38.5^{\mathrm{b}}$ & $38.7^{\mathrm{b}}$ & $35.6^{\mathrm{b}}$ & $34.9^{\mathrm{b}}$ & $35.5^{\mathrm{b}}$ \\
\hline $3 \mathrm{X}$ & & $41.4^{\mathrm{a}}$ & $43.2^{\mathrm{a}}$ & $42.3^{\mathrm{a}}$ & $37.2^{\mathrm{a}}$ & $36.6^{\mathrm{a}}$ & $37.7^{\mathrm{a}}$ \\
\hline SEM & & 0.5 & 0.5 & 0.5 & 0.4 & 0.4 & 0.4 \\
\hline $2 \mathrm{X}$ & $\begin{array}{l}\text { Region }^{1} \\
\text { North }\end{array}$ & $39.1^{\mathrm{ab}}$ & 39.3 & 39.3 & $35.4^{\mathrm{b}}$ & 35.0 & 35.3 \\
\hline $2 \mathrm{X}$ & South & $37.6^{\mathrm{b}}$ & 37.6 & 38.0 & $35.9^{\mathrm{b}}$ & 34.8 & 35.8 \\
\hline $3 \mathrm{X}$ & North & $40.2^{\mathrm{a}}$ & 43.4 & 43.2 & $35.6^{\mathrm{b}}$ & 36.6 & 36.1 \\
\hline $3 \mathrm{X}$ & South & $42.6^{\mathrm{a}}$ & 43.0 & 41.4 & $38.8^{\mathrm{a}}$ & 36.5 & 39.2 \\
\hline SEM & & 0.7 & 0.7 & 0.7 & 0.5 & 0.5 & 0.5 \\
\hline
\end{tabular}

\footnotetext{
${ }^{\mathrm{ab}}$ Least squares means within column for main effect or interaction with the same superscripts do not differ $(\mathrm{P}<0.05)$.

${ }^{1}$ Regions are North and South (see Figure 1).
}

adverse effect on longevity by milking cows $3 \mathrm{X}$. Culling rate was not related to the production response that occurred with 3X milking according to Gisi et al. (1986). In our study, herds milked $3 \mathrm{X}$ increased in size more rapidly than herds milked $2 \mathrm{X}$. The net change $(\%$ of cows entering - $\%$ of cows leaving) was $2.8,3.6$, and $3.2 \%$ for herds milked $2 \mathrm{X}$, and $4.2,6.6$, and $4.6 \%$ for herds milked $3 X$ for 1998, 1999, and 2000, respectively.

\section{CONCLUSIONS}

Previous studies on MF have been limited to a relatively few herds. Our study is the first to investigate MF with a large number of herds sorted by region. Milk yield, as expected, was higher for herds milked 3X. However, milk fat and milk protein percentages were significantly lower for herds milked 3X. As a result of lower milk component percentages, the milk production advantage of herds milked $3 \mathrm{X}$ was reduced when yields were measured by ECM. When evaluating the economics of milking $3 \mathrm{X}$, an analysis beyond the scope of this report, consideration should be given to the lower component percentages, especially for herds paid for both milk fat and protein.

Based on this study, those contemplating milking $3 \mathrm{X}$ should expect an increase of approximately 13 to $14 \%$ in ECM. Reproductive efficiency is slightly lower for herds milking $3 \mathrm{X}$ compared to herds milked $2 \mathrm{X}$, but udder health as measured by SCC may be improved. Culling rates are slightly higher for herds milked $3 \mathrm{X}$.

\section{REFERENCES}

Allen, D. B., E. J. DePeters, and R. C. Laben. 1986. Three times a day milking: Effects on milk production, reproductive efficiency, and udder health. J. Dairy Sci. 69:1441-1446.

Amos, H. E., T. Kiser, and M. Loewenstein. 1985. Influence of milking frequency on productive and reproductive efficiencies of dairy cows. J. Dairy Sci. 68:732-739.

Barnes, M. A., R. E. Pearson, and A. J. Lukes-Wilson. 1990. Effects of milking frequency and selection for milk yield on productive efficiency of Holstein cows. J. Dairy Sci. 73:1603-1611.

Butler, W. R., and R. D. Smith. 1989. Interrelationships between energy balance and postpartum function in dairy cattle. J. Dairy Sci. 72:767-783.

Campos, M. S., C. J. Wilcox, H. H. Head, D. W. Webb, and J. Hayen. 1994. Effects of production of milking three times daily on first lactation Holstein and Jerseys in Florida. J. Dairy Sci. 77:770773.

Culotta, C. P., and G. H. Schmidt. 1988. An economic evaluation of three times daily milking of dairy cows. 1988. J. Dairy Sci. 71:1960-1966.

DePeters, E. J., N. E. Smith, and J. Acedo-Rico. 1985. Three or two times daily milking of older cows and first lactation cows for entire lactations. J. Dairy Sci. 68:123-132.

Erdman, R. A., and M. Varner. 1995. Fixed yield responses to increased milking frequency. J. Dairy Sci. 78:1199-1203.

Gisi, D. D., E. J. DePeters, and C. L. Pelissier. 1986. Three times daily milking of cows in California dairy herds. J. Dairy Sci. 69:863-868. 
Hogeveen, H., J. D. Miltenburg, S. den Hollander, and K. Frankena. 2001. Milking three times a day and its effect on milk production health. International Dairy Federation. Mastitis Newsletter. 24:7.

Klei, L. R., J. M. Lynch, D. M. Barbano, P. A. Oltenacu, A. J. Lednor, and D. K. Bandler. 1997. Influence of milking three times a day on milk quality. J. Dairy Sci. 80:427-436.

Lacy-Hulbert, S. J., M. W. Woolford, G. N. Nicholas, C. G. Prosser, and K. Stelwagen. 1999. Effect of milking frequency and pasture intake on milk yield and composition of late lactation cows. J. Dairy Sci. 82:1232-1239.

Pearson, R. E., L. A. Fulton, P. D. Thompson, and J. W. Smith. 1979. Three times a day milking during the first half of lactation. J. Dairy Sci. 62:1941-1950.

Sapru, A., D. M. Barbano, J. J. Yun, L. R. Klei, P. A. Oltenacu, and D. K. Bandler. 1997. Cheddar Cheese: Influence of milking frequency and stage of lactation on composition and yield. J. Dairy Sci. 80:437-446.

SAS/STAT User's Guide: Statistics, Version 6.12 Edition. 1996. SAS Inst., Inc., Cary, NC.

SAS/STAT Software: Changes and Enhancements through Release 6.12. 1997. SAS Inst., Inc., Cary, NC.

Spaulding, R. N., R. W. Everett, and R. H. Foote. 1975. Fertility on New York artificially inseminated Holstein herds in dairy herd improvement. J. Dairy Sci. 58:718-723.

Speicher, J. A., H. A. Tucker, R. W. Ashley, E. P. Stanisiewski, J. F. Boucher, and C. J. Sniffen. 1994. Production responses of cows to recombinantly derived bovine somatotropin and to frequency of milking. J. Dairy Sci. 77: 2509-2517.

Waterman, D. F., R. J. Harmon, R. W. Hemken, and B. E. Langlois, 1983. Milking frequency as related to udder health and milk production. J. Dairy Sci. 66:253-258. 